\title{
4DVARを用いた台風9918号の追算 \\ Hindcasting Coastal Sea Surface Wind by 4DVAR at Typhoon 9918
}

\author{
中野俊夫 ${ }^{1}$. 山城 賢 $^{2} \cdot$ 橋本典明 $^{3} \cdot$ 大西健二 $^{4}$ \\ Toshio NAKANO, Masaru YAMASHIRO, Noriaki HASHIMOTO and Kenji OHNISHI
}

\begin{abstract}
Accurate hindcasting of sea surface winds under typhoon conditions is great importance for various purposes. Recently several data assimilation technique and typhoon bogus scheme have been evolved to meet the increasing demand for accuracy improvement of typhoon intensity and track. Among them, however, previous data assimilation technique, nudging, is incomplete to deal with typhoons since it has detrimental effect of smoothing as well as inconsistent dynamic balance in the analyzed wind field. In this study, therefore, we apply the 4DVAR(fourdimensional variational data assimilation), one of the most advanced data assimilation techniques, to hindcast the coastal sea surface winds at Typhoon 9918. As a result, accuracy improvement is confirmed in both intensity and track of the typhoon.
\end{abstract}

\section{1.はじめに}

台風による沿岸の局地的な強風や波浪・高潮の再現 は，防波堤や護岸の設計をする上で重要な問題である. 近年では，気象モデルを用いて台風の強度と進路の追算 精度を高め, 強風を再現する研究が行われてきた. 強度 に関しては，例えば吉野ら（2008）は，台風ボーガスを 用いて台風の構造を表現し，解析值に埋め込むことで一 定の成果を挙げてきた。進路に関しては，簡易的な 4 次 元同化手法であるNudgingを用いて精度向上が図られて きた（中野ら，2006）。しかし， Nudgingには，(1)スムー ジングの影響があるため, 台風の強度を過小評価する傾 向がある, (2)解析值の時間変化に対して追算值の時間変 化が遅れる，(3)強制項を与えているため，追算された計 算值は，力学的にバランスした場とは言えないという問 題があり，進路の追算精度は十分ではなかった。

一方で，近年ではデー夕同化理論の進歩と計算機性能 の著しい向上により，高度な同化手法である4DVAR（4Dimentional Variational Data Assimilation）が利用可能にな ってきた. 4DVARは, 現在, 行われている同化手法の 中でもっとも高度な同化手法の一つであり, 物理法則を 拘束条件として，連続的に同化期間中の観測デー夕を同 化することができる（露木ら，2008）。そのため， 4DVARでは大気の流れに沿った修正を行うことができ, 解析された場は力学的整合性を保ち, スムージングなど

\begin{tabular}{lll}
\hline 1 & 修(理) & $\begin{array}{l}\text { 一般財団法人日本気象協会事業本部防災 } \\
\text { 事業部防災事業課 } \\
\text { 九州大学大学院工学研究院環境都市部門 }\end{array}$ \\
3 & フェロー 博 (工) & $\begin{array}{l}\text { 助教 } \\
\text { 九州大学大学院工学研究院環境都市部門 } \\
\text { 教授 } \\
\text { 一般財団法人日本気象協会事業本部防災 } \\
\text { 事業部海洋課 }\end{array}$
\end{tabular}

の影響も生じない.

4DVARは，(1)世界各地の気象センターによる現業予 報や，(2)様々なデー夕を同化することにより台風時の降 水予報精度を向上させる研究（Huangら，2009）など, さまざまな目的で利用され，短期の予報精度向上におい て顕著な成果を挙げてきている.

そこで, 本研究では, 4DVARを適用して台風ボーガ スデー夕を同化することで, 従来手法では再現が困難で あった台風9918号（日本気象協会，2005）を対象に海上 風追算精度の向上を図った。

\section{2. 計算手法}

\section{（1）気象モデル}

気象モデルには，メソ気象モデルWRF（Weather Research and Forecasting Model）を用いた. WRFは，米 国大気研究センター (NCAR), 米国環境予測センター (NCEP), 米国海洋大気庁 (NOAA/FSL), 米国空軍気象 局（AFWA）などが中心となって開発した圧縮性の非静 力学モデルで, 物理過程, 放射過程, 境界層過程, 地表 面過程を含んでいる.

計算領域は，台風全体を覆う $1000 \mathrm{~km} \times 1000 \mathrm{~km}$ とし， 水平格子間隔は, 台風の構造を解像できる $10 \mathrm{~km}$ とした. 図-1に計算領域と, 海上風の精度検証を行った観測地点 を示す.

鉛直方向の気圧準拠座標（ $\sigma$ 座標）については，地表 から $100 \mathrm{hPa}$ までに 32 層を設定し, 最下層を $\sigma=0.997$ と して，800hPaより下層の大気境界層内に 12 層を集中させ た. 気象場の初期・境界值には, 気象庁から公表されて いる水平格子間隔 $20 \mathrm{~km}$ の領域客観解析值（以下, RANAL ゙゙ー夕) と, 水平格子間隔 0.25 度の海面水温 （Near-goos）を与えた. 


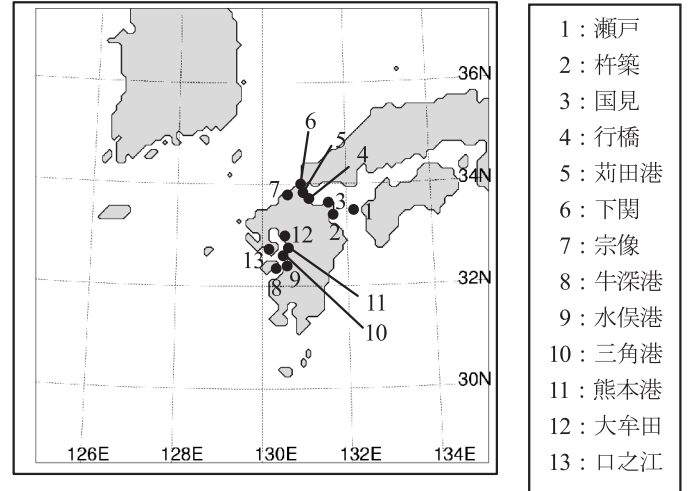

図-1 計算領域図

\section{（2）従来の同化手法（Nudging）}

Nudgingは, 式（1）で示すように，タイムステップ毎 に観測值の情報を外力として与える連続同化手法である (Guo ら, 1994).

$$
\frac{\partial \alpha(x, t)}{\partial t}=F(\alpha, x, t)+G\left[\alpha_{a}(x, t)-\alpha(x, t)\right]
$$

ここで， $\alpha$ は予報変数（風, 気温, 比湿）で, $\alpha_{a}$ は予 報変数の解析值である. F は予報変数に変化を与えるす べての物理過程を含む予報式で, 時間・場所に依存して 変化する. Gはナッジング係数で, 解析值へどの程度近 づけるかを決める係数であり, 解析值の精度と計算值の 精度のバランス, 解析值の時間密度に依存する. 本計算 では，3.0×10-4 とした.

\section{（3）新たな同化手法（4DVAR）}

4DVARモデルには，メソ気象モデルWRFに対して開 発された変分法に基づくデータ同化システム WRF-Var （Barkerら，2005）を用いた. WRF-Varでは，以下の式 (2) 〜 (5) で示されるコスト関数Jが最小值となる最適 値ベクトルを探索する.

$$
\begin{aligned}
& J=J_{b}+J_{o}+J_{c} \\
& J_{b}=\frac{1}{2}\left(X^{n}-X^{b}\right) B^{-1}\left(X^{n}-X^{b}\right) \\
& J_{o}=\frac{1}{2} \sum_{k=1}^{K}\left[H_{k}\left[M_{k}\left(X^{n}\right)\right]-Y_{k}\right]^{T} R^{-1}\left[H_{k}\left[M_{k}\left(X^{n}\right)\right]-Y_{k}\right] \\
& J_{c}=\frac{1}{2} \gamma_{d f}\left[\sum_{i=0}^{N} g_{i} M_{i}\left(X^{n}-X^{n-1}\right)\right]^{T} C^{-1}\left[\sum_{i=0}^{N} g_{i}\left(X^{n}-X^{n-1}\right)\right]
\end{aligned}
$$

$J_{b}$ は第一推定值からの差を測る項で， $J_{o}$ は観測值からの 差を測る項， $J_{c}$ は解析值に含まれる重力波の量を調整す るペナルティ項である. $X^{b}$ は, モデル変数の第一推定值 ベクトル， $Y_{k}$ は時刻 $k$ における観測值ベクトルである. $H$ は, 観測演算子で, モデル変数 $X$ を観測值の単位や量に 変換する演算子 $(Y=H(x))$ である. $R, B$ はそれぞれ観 測值の誤差共分散行列および背景誤差共分散行列であ る. $\gamma_{d f}$ は $J_{c}$ 項における係数, $g$ はデジタルフィルタに関
する係数, $C$ は風や気温などの分散を含む対角行列であ る.ここで添え字 $T$ は行列の転置を意味する。 $M$ は気象 モデルの時間推進演算子で, $M^{T}$ はアジョイントモデルの 時間推進演算子である.

4DVARでは, この時間推進演算子を用いることで, 物理法則にしたがって解析值の時間変化が観測值の時間 変化に近づくように解析を行うため, 解析された場は力 学的整合性を保っており, その後の大気の流れに連続的 につながる初期值を作成することができる，ただし，時 間推進演算子は気象モデルを積分することに相当するた め, 最適值べクトルを求めるには通常の追算の数十倍か ら数百倍の計算時間を要する. 本研究では, 台風の進路 （台風中心の移動経路）の追算誤差が十分減少するまで 計算を行い, 収束させた。

背景誤差共分散行列は, NMC (National Meteorological Center）法から推定した（Parrishら，1992）。NMC法は, ある時刻に対する 24 時間予測值と 12 時間予測值の差を 一定期間蓄積して, 統計解析に用いる手法である. 本研 究では, 計算対象時刻の前後 1 週間の解析から求めた.

\section{(4) 観測値}

観測值は, 気象庁で現業的に使用されている台風ボー ガス手法（大澤ら，2001）から得られる風・高度・気温 を擬似観測值として与えた。このボーガスは, 気圧分布 をFujita（1952）の経験式を用いて表し, 高度D值（台風 半径内の等圧面高度 $Z$ の周辺值からの偏差）の3次元構 造を複数の台風のコンポジット解析から求められた解析 関数を用いて記述するものである. 4DVARに投入する 観測值の密度は, 水平方向は $20 \mathrm{~km}$ 間隔とし, 鉛直方向 については，モデルの鉛直格子と同じ密度とした.

\section{3. 従来手法と ADVARの比較}

\section{（1）台風9918の概況}

台風9918号は，強い勢力を持って 1999年9月 24 日 6 時 に八代海に上陸し，周防灘に抜けた台風である。この台 風の通過に伴い, 八代海に面した熊本県不知火町では高 潮によって死者 12 名の未曾有の被害が生じた。しかし, この台風は, RANALでは, 台風を過小評価しており, 気象モデルでの再現が困難な事例であった.

図-2に台風9918号の気象庁領域数值予報モデル（以下 RSM）の予報結果とベストトラックの台風進路と中心気 圧の時系列変化図を示す. RSMの初期時刻は, 八代海に 上陸した1999年9月24日6時の直近である9月23日21時 とした。これによると, RSMの予報結果は, ベストトラ ックと比較して台風の進行が遅れており, 台風中心が八 代海にもっとも接近した 24 日 6 時では, $70.2 \mathrm{~km}$ の進路誤 差であった。台風の中心気圧は, ベストトラックと比較 して高く，台風強度を過小評価しており，24日6時では， 
22.7hPaの誤差であった.

以上から, 台風9918では, 初期 ·境界条件を与える気 象庁データの台風進路や強度の予測精度が十分でなかっ たことが分かる．したがって，本事例では台風ボーガス やデー夕同化を用いて台風進路や強度を制御し，再現性 を向上する必要があった。

\section{（2）各手法の計算結果}

本研究では，デー夕同化手法による追算精度の比較を 行うため，(1)データ同化なし，(2)従来手法（Nudging）, (3)新手法（4DVAR）について検討した.

追算期間については，台風が八代海や周防灘に接近し た時刻に注目し，初期時刻を台風が八代海に上陸する 3 時間前の 1999 年 9 月 24 日 3 時，終了時間を台風が周防灘 に上陸する9月 24 日 8 時の 5 時間とした。図-3に，各手法 の追算結果とベストトラックの台風進路と進路誤差の時 系列変化図を示す.

デー夕同化なしは，進路がベストトラックに対して南 西側にずれており，24日6時にはベストトラックが台風 中心を熊本県の北西部に解析しているのに対し，追算值 は長崎県諫早市付近に解析していた。従来手法は，デー 夕同化なしと比較して改善されているものの，進路が西 側にずれており，24日6時には台風中心を福岡県の南西 部に解析していた。一方，4DVARは，ベストトラック

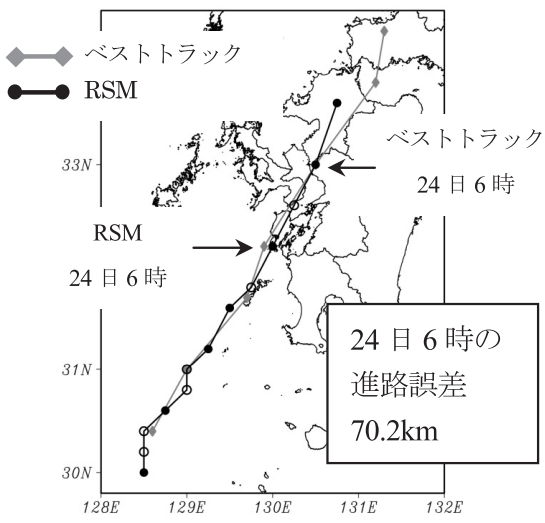

(a) 台風進路

(白抜きは，ベストトラック值のない時刻)

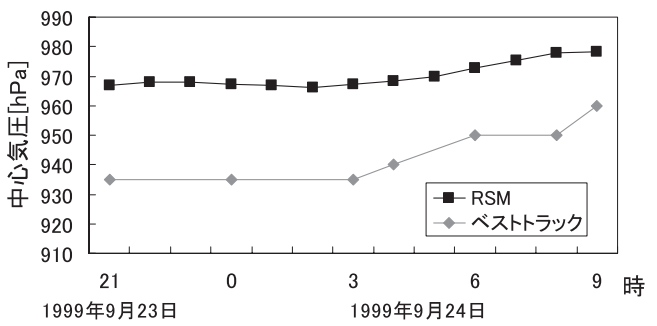

(b) 台風の中心気圧の時系列変化

図-2 気象庁RSMの予報結果とベストトラックの比較
とほぼ同じ進路をとっており，進路が改善されていた。

進路誤差の時系列変化では，同化なしや従来手法は時 間とともに進路誤差が増加し，24日8時には，同化なし $70.9 \mathrm{~km}$ ，従来手法 $45.4 \mathrm{~km}$ に達していたが，4DVARはほ ぼ一定で24日8時で $15.9 \mathrm{~km}$ であった。

これは，従来手法では，観測值と追算值との誤差が生 じた後，その誤差を解消するように強制力が働いて修正 が行われるのに対し，4DVARでは，同化期間内のすべ ての観測值に近づくように連続的に解析して修正するた め，追算期間内全体の台風進路の再現性が向上したと考 える。以上から，進路追算精度は，4DVARがもっとも 高いと考えられる。なお，各手法とも24日3時の初期時 刻で台風中心がベストトラックと一致していない（誤差 は3.6km）のは，格子間隔が $10 \mathrm{~km}$ であるために生じた表 現誤差である。この誤差は，数值計算では避けられない ものであるが，4DVARでは初期時刻以降に進路誤差が 大きく増加していないことから，追算精度には大きな影 響を与えていないと考える。図-4に，各手法の追算結果 とベストトラックの台風の中心気圧の時系列変化を示す.

同化なしは，ベストトラックと比較して 24 日 4 時は

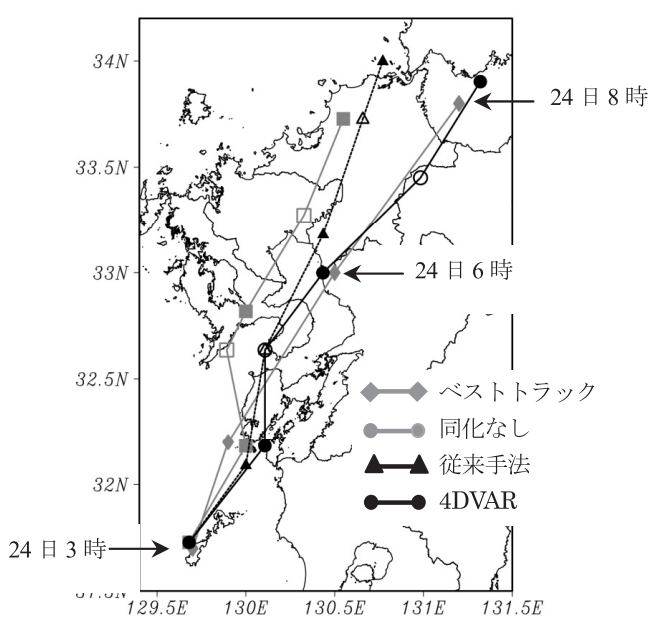

(a) 台風進路

（白抜きはベストトラック值のない時刻）

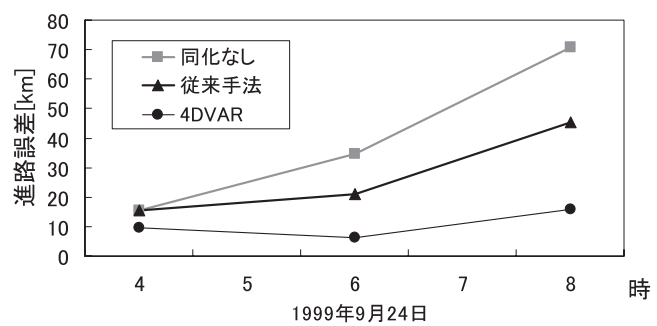

(b) 進路誤差の時系列変化

図-3 各手法の追算結果とベストトラックの比較 


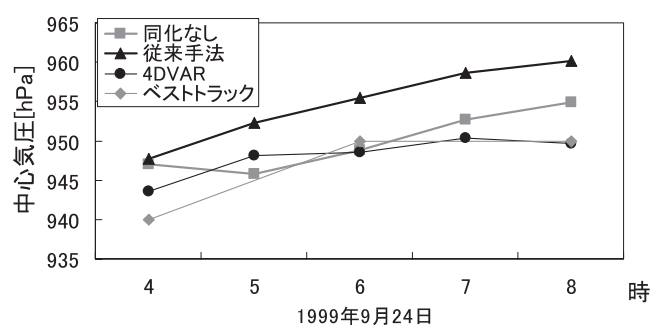

図-4 各手法とベストトラックの中心気圧の時系列変化

$7.0 \mathrm{hPa}$ 気圧が高かった。 24 日6時には誤差は $1.2 \mathrm{hPa}$ と減 少したが，24日8時には誤差 $4.9 \mathrm{hPa}$ と再び増加していた. 従来手法は, 追算期間を通して, ベストトラックと比較 して $5 \mathrm{hPa}$ 以上, 高くなっていた.これは, Nudgingによ るスムージングの影響で台風が衰弱し, 強度が過小評価 になったためと考える.4DVARは，24日4時に3.6hPaの 誤差であったが，24日 6 時に $1.8 \mathrm{hPa} ， 24$ 日 8 時に $0.4 \mathrm{hPa}$ の誤差と, 台風の中心気圧の時系列変化をよく再現して いた. 以上から，強度追算精度についても，4DVARが もっとも精度が高いと考えられる.

24 日6時の港湾関係省庁と, AMeDAS の風向風速観測 值を図-5に, 各手法の $10 \mathrm{~m}$ 高度風速, 海面更正気圧分布 を図-6に示す。当該時刻では台風の中心は熊本県北西部 に上陸しており, 中心気圧は $950 \mathrm{hPa}$ であった。同化なし では，948.8hPa と強度誤差は小さかったが進路誤差は $34.6 \mathrm{~km}$ であった。 従来手法は, 進路誤差は $21.0 \mathrm{~km}$ と減少 していたが, 中心気圧は $955.5 \mathrm{hPa}$ と強度を $5.5 \mathrm{hPa}$ 過小評 価していた. 4DVARは, 進路誤差が $6.2 \mathrm{~km}$ でもっとも小 さく中心気圧が948.6hPa と強度誤差も小さかった。

観測された風の分布では, 八代海・有明海を中心とし た渦が観測され, 周防灘には豊後水道を抜けてきた強風
が吹き达んでいた，同化なしは，台風中心が南西にずれ ているため佐賀では観測值は南向きの風であったのに対 し, 追算值では北向きの風であった。従来手法も, 渦の 中心が北にずれているため, 台風中心に近い大牟田では 観測值の風向が南南東に対し追算值は南南西, 三角港で は観測值の南西に対して追算值は南南西と風向に誤差が 生じていた. 一方, 4DVARでは, 台風の中心位置の追 算精度が高く, 大牟田や三角港においても, 観測と同じ 風向を追算していた. 台風時においては, 台風中心に対 する相対的な位置によって, 風向が大きく異なる。した がって, 台風時の風を高精度に追算するためには, 台風 の中心位置を正確に追算することが重要であり, 本時刻 では，4DVARの精度がもっとも高かったと考えられる。

次に, 各手法の海上風の追算精度の評価を行うため, 東西風速, 南北風速に分けて相関係数を算出した. 東西 風速・南北風速に分けることにより, 風向も考慮した評 価指標になる．観測地点は，比較的海上風を捉えている

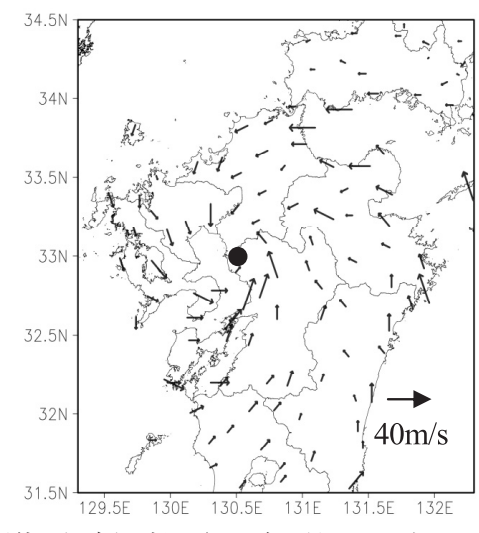

図-5＼cjkstart観測值の風向風速図（1999年9月24日6時, ○は台風中心） (a)同化なし

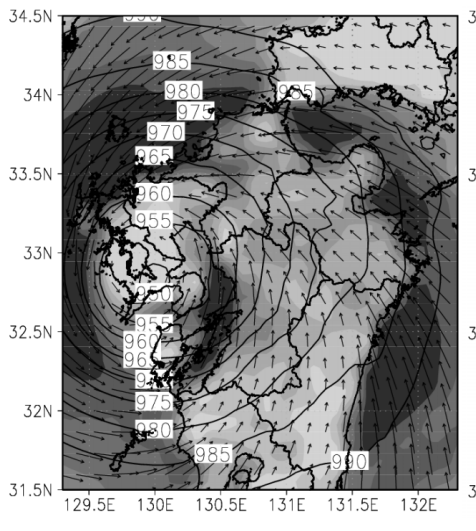

(b)従来手法

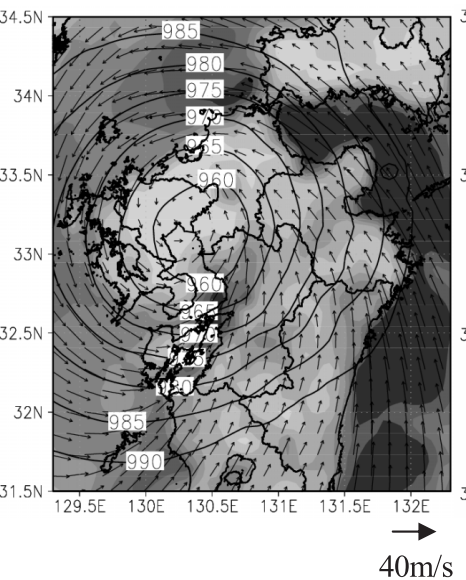

(c)4DVAR

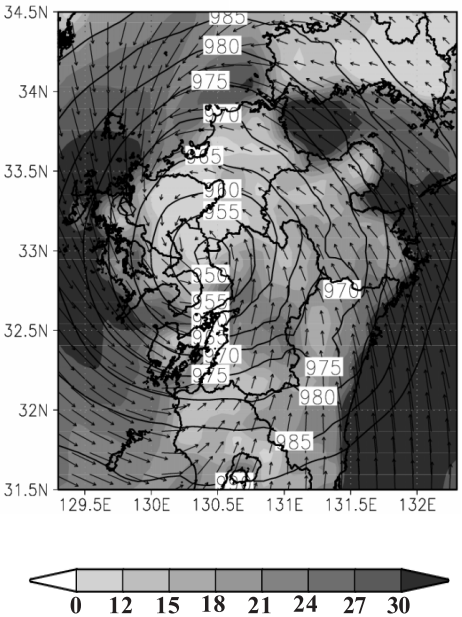

図-6 各手法の $10 \mathrm{~m}$ 高度風速（陰影部，単位： $\mathrm{m} / \mathrm{s}$ ）と気圧（実線，単位：hPa）分布（1999年9月24日6時） 
と考えられる地点として, 八代海・周防灘近辺の港湾関 係省庁の観測地点（三角港, 熊本港, 牛深港, 水俣港, 苅田港）と，海岸線からの距離が短い AMeDAS 地点（大 牟田，下関，口之江，国見，瀬戸，宗像，杵築，行橋) とした (図-1参照)。図-7に，各手法の観測値と追算值の 相関係数の時系列変化図を示す.

$1 \sim 2$ 時間追算值については，4DVARがもっとも相関 係数が高く, 次いで同化なし, 従来手法であった. 台風 中心が八代海に接近した24日6時においては，4DVARが 相関係数 0.90 ともっとも高く, 従来手法 0.87 , 同化なし 0.77 であった。また，台風中心が周防灘に接近した 24 日 8 時においても, 4 DVARが相関係数 0.88 ともっとも高く, 従来手法 0.85 , 同化なし 0.59 であり, 台風中心が観測地 点に接近している時刻ほど, 精度の差が大きかった。こ れは, 台風中心が観測地点に接近するほど, 進路や強度 の追算精度が海上風の追算精度に大きく影響するためで ある、したがって, 台風中心が日本近海に接近して災害 などを引き起こした事例において，海上風の追算精度向 上を図る場合には，4DVARなどの高度な同化手法を用 いて台風の進路や強度の追算精度を向上させる必要があ ると考えられる。

\section{4. 結語}

本研究では, 台風による内湾の局地的な強風の追算精 度を向上させるため, 新たな同化手法である4DVARを 用いて，台風ボーガスの同化を行った。主な結果は，以 下のようである.

（1）台風の進路追算については，4DVARは，同化期間 内のすべての観測值に近づくように連続的に解析して 初期值を修正するため, 従来手法と比較して精度が高

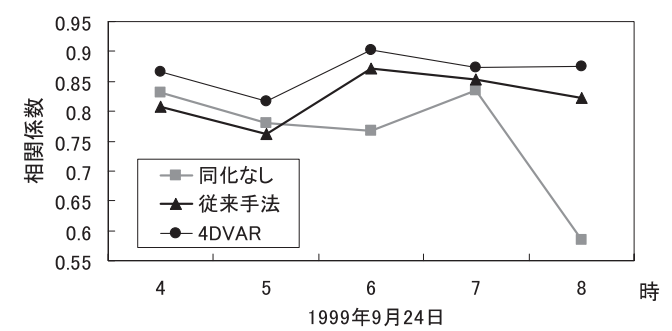

図-7 各手法による風速相関係数の経時変化
かった。

（2）台風の強度追算については，4DVARは, 従来手法 のようにスムージングの影響で台風強度を過小評価す る傾向がなく, 従来手法と比較して精度が高かった。

（3）海上風の追算については，東西風速・南北風速に分 けて相関係数を算出したところ，4DVARは，従来手 法や同化なしと比較して, 精度が高かった。

ただし, 本研究では, 一事例のみの解析にとどまって いることから, 今後は様々な事例で精度検証を行い, 一 般性のある手法の確立を目指す必要がある。また，本研 究で開発した海上風を, 波浪・高潮モデルに適用し, 台 風時の波浪・高潮の追算精度向上を図る予定である.

最後に, 本研究の一部は, 科学研究費補助金20360222 の成果であり，ここに記して謝意を表する。

\section{参考文 献}

大澤輝夫・竹山剛生・安田孝志 (2001)：メソ気象モデルと台 風ボーガスを用いた伊勢湾台風時の風の場のシミュレー ション，海岸工学論文集，第48卷，pp. 281-285.

露木 義・川畑拓矢 (2008): 気象学に扔けるデー夕同化, 気 象研究ノート, 第 217 号, $277 \mathrm{p}$.

中野俊夫 · 大澤輝夫 - 吉野 純 - 益子 涉 - 河合弘泰 - 松浦 邦明（2006）：台風ボーガスの高度化による数值予報モデ ルを用いた海上風推算手法の精度向上, 海岸工学論文集, 第 53卷, pp. 1286-1290.

(財) 日本気像協会 (2005): 台風時の内湾海上風推算の研究 （その1）報告書, 日本財団助成, $101 \mathrm{p}$

吉野 純・児島弘展・安田孝志 (2008)：台風予測精度向上の ための渦位に基づく新しい台風ボーガス手法の構築，海 岸工学論文集, 第 55 卷, pp. 436-440.

Barker, D.M., M.S. Lee, Y.-R. Guo, W.Huang, S.Rizvi, Q.-N.Xizo, Y.-H.Kuo, J.Gu, X.-Y.Huang, and M.-S. Lee (2005): WRF-VarA unified 3/4D-Var variational data assimilataion system for WRF. Sixth WRF/1 $5^{\text {th }}$ MM5 Users' Workshop, Boulder, CO, NCAR, $17 \mathrm{pp}$.

Fujita, T. (1952): Pressure distribution within typhoon, Geophys. Mag, vol23, pp. 437-451

Guo, Y. R. and Y. H. Kuo (1994): Testing of Newtonian nudging technique in data assimilation on the meso-beta-scale, Proc. of the Fourth Atmospheric Radiation Measurement(ARM) Science Team Meeting, Charleston, South Carolina., pp. 167-171.

Huang X-Y. (2009): Four-Dimensional Variational Data Assimilation for WRF: Formulation and Preliminary Results. Monthly Weather Review 137. pp. 299-314

Parrish,D.F., and J.C. Derbber (1992): The National Meteorological Center ${ }^{1}$ s Spectral Statistical Interpolation analysis system. Monthly Weather Review 120, pp. 1747-1763. 